\title{
Türkiye’de kadınların aile planlaması yöntemleri kullanma durumları ve tutumları: Sistematik derleme
}

\author{
Esma GAVAS ${ }^{\mathrm{a}}$, Sevil İNAL ${ }^{\mathrm{b}}$
}

\begin{abstract}
ÖZET
Amaç: Bu derleme, Türkiye'deki kadınların aile planlaması (AP) yöntemleri kullanma durumlarının ve AP yöntemleri kullanımına yönelik tutumlarının belirlenmesi amacıyla yapılmıştır. Yöntem: Sistematik derleme niteliğindeki bu araştırmada; elde edilen sonuçlar, araştırmanın yapıldığı yer, araştırma yöntemi, araştırma kapsamı ve sonuçları bakımından sistematik bir şekilde ele alındı ve sonuçlar tartışma bölümünde irdelendi. AP yöntemleri, kadın, Türkiye, kadın sağlığı, aile planlaması anahtar kelimeleri girilerek, Web of Science, Pubmed, Science Direct, Medline, Ovid, Pro Quest, Google Akademik, ULAK BİM Türk Tıp Dizini veri tabanları, tez merkezi, üniversitelerin kütüphanelerinde bu konuda yapılmış tezler incelenerek, 2007 2017 yılları arasında yapılmış toplam 12 çalışma araştırmaya dahil edildi. Bulgular: Kullanılan aile planlaması yöntemlerinin dağılımı incelendiğinde, araştırmaya göre oldukça değişen oranlarda farklı aile planlaması yöntemlerinin tercih edildiği belirlendi. Geleneksel bir yöntem olan geri çekme yönteminin araştırmaya göre değişmekle birlikte ilk sıralarda tercih edilen yöntemlerden biri olduğu saptandı (\%9.1-\%61.3). Kondom kullanım oranı \%13.2- \%47.3 arasında, rahim içi araç kullanım oranı \%19.1'i - \%25.2 ve hap kullanım oranı \%13.9-\%50.9 arasında değişmekteydi. Çoğu çalışmada sosyal güvencesi olanların, eğitim düzeyi yüksek olanların, çalışan kadınların Aile Planlaması Tutum Ölçeği puanlarının daha yüksek olduğu belirlendi. Sonuçlar: Türkiye'deki kadınların aile planlaması yöntemleri hakkında bilgi düzeylerinin düşük olduğu ve AP yöntemlerini etkili şekilde kullanmadığı görülmektedir. Modern aile planlaması yöntemi kullanma oranı düşük, geri çekme yöntemi kullanma oranı yüksektir. Eğitimli, sosyal güvencesi olan ve çalışan kadınların, aile planlaması yöntemleri kullanımı ile ilgili tutumlarının daha olumlu olduğu belirlenmiştir. Bu araştırmadan elde edilen sonuçların Türkiye'de kadınların AP yöntemleri kullanma durumlarının ve AP yöntemlerine ilişkin tutumlarının belirlenmesinin, kadınlara AP konusunda yapılacak eğitimlerin planlanmasında yol gösterici olacağı düşünülmektedir.
\end{abstract}

Anahtar Kelimler: Aile planlaması yöntemleri, kadın, kadın sağlı̆̆ı, Türkiye
The family planning methods using status and attitudes of women in Turkey: A systematic review

\begin{abstract}
Aim: The aim of this study is to determine the situation of women in Turkey regarding their utilization of family planning (FP) methods and their attitudes toward the use of FP methods. Method: In this systematic review; the results obtained were systematically discussed in terms of the place of the research, research method, scope, and results of the research, and the results were discussed in the discussion section. Web of Science, Pub med, Science Direct, Medline, Ovid, Pro Quest, and Google Academic, ULAKBİM, Turkish Medical Directory databases, thesis center and the theses which are about this subject in universities' libraries have been scanned using FP methods, women, Turkey, women's health, family planning keywords. Twelve research published between 2007 and 2017 was included in the study. Results: When the distribution of family planning methods used was examined, it was determined that different family planning methods were preferred in fairly varying proportions according to the research. The withdrawal method, which is a traditional method, was found to be one of the most preferred methods (9.1-61.3\%). The rate of condom use ranged from $13.2 \%$ to $47.3 \%$, the rate of intrauterine device use ranged from $19.1 \%$ to $25.2 \%$ and the rate of pill use ranged from $13.9 \%$ to $50.9 \%$. In most of the studies, it was found out that women who have social security, high education level, and are working had higher Family Planning Attitude Scale scores. Conclusions: It is observed that women have less information about family planning methods and the FP methods are not used effectively by women in Turkey. The rate of the use of the modern family planning method is low and the rate of using the withdrawal method is high. It was determined that educated, socially insured and working women had more positive attitudes towards the use of family planning methods. According to the results obtained from the study, it is thought that determining the situation of using family planning methods and the women's attitudes to FP methods will guide the planning of the training in Turkey regarding FP methods.
\end{abstract}

Key Words: Family planning methods, women, women health, Turkey

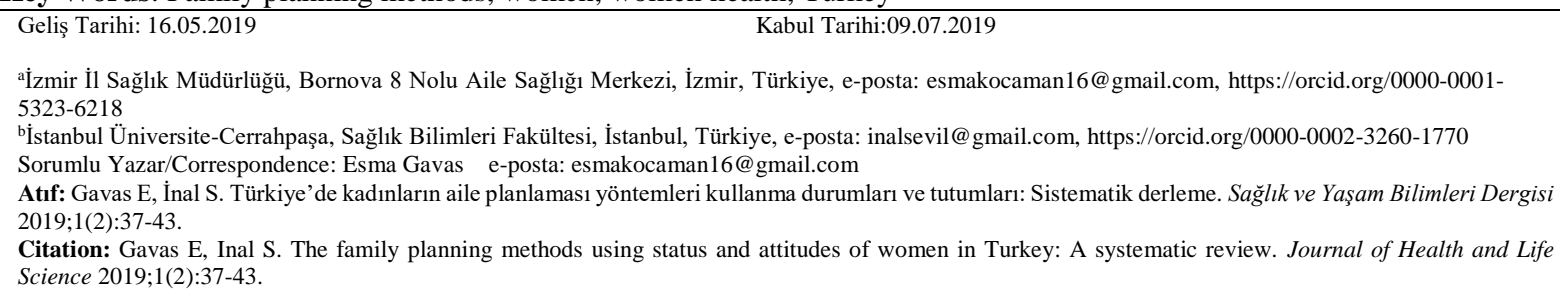

ȧ̇zmir İl Sağlık Müdürlüğü, Bornova 8 Nolu Aile Sağlı̆̆ı Merkezi, İzmir, Türkiye, e-posta: esmakocaman16@gmail.com, https://orcid.org/0000-00015323-6218

bİstanbul Üniversite-Cerrahpaşa, Sağlık Bilimleri Fakültesi, İstanbul, Türkiye, e-posta: inalsevil@ gmail.com, https://orcid.org/0000-0002-3260-1770 Sorumlu Yazar/Correspondence: Esma Gavas e-posta: esmakocaman16@gmail.com

Atıf: Gavas E, İnal S. Türkiye'de kadınların aile planlaması yöntemleri kullanma durumları ve tutumları: Sistematik derleme. Sağlık ve Yaşam Bilimleri Dergisi 2019;1(2):37-43.

Citation: Gavas E, Inal S. The family planning methods using status and attitudes of women in Turkey: A systematic review. Journal of Health and Life Science 2019;1(2):37-43. 


\section{GíRiş}

Aile planlaması (AP) bireylerin istenmeyen gebeliklerden korunmalarına, gebelikleri arasındaki sürenin düzenlenmesine, istedikleri zaman ve istedikleri sayıda çocuk sahibi olmalarına, çocuğu olmayan bireylerin çocuk sahibi olmalarına olanak sağlayan bir uygulamadır. ${ }^{1}$ AP yöntemleri, anne ve bebek sağlığını olumsuz etkileyen aşırı doğurganlığı önleyerek, kadın ve çocuk sağlı̆̆ının yanı sıra toplumun sağlığının korunması ve geliştirilmesine önemli katkılar sağlamaktadır. ${ }^{1-4}$

Bireylerin AP yöntemleri hakkında bilgi sahibi olması ve AP yöntemlerine erişebilirliği, gebeliği önleyici yöntem kullanıp kullanmama kararlarının yanı sıra, kullanacakları yöntemi seçmesini de önemli ölçüde etkilemektedir. Gelişmekte olan ülkelerde, doğum sayısının fazla olması anne ölüm nedenleri arasında ilk sirada yer almaktadır. ${ }^{5} \mathrm{Bu}$ nedenle, AP hizmetlerinin etkin şekilde sunulması, hem kadın ve çocuk hem de toplum sağlığına önemli katkılar sağlamaktadır.,

Bireyler, sahip olmak istedikleri çocuk sayısı ve ne zaman sahip olmak istedikleri konusunda karar verme hakkına sahiptirler. Ülkemizde AP hizmetleri 1965 yılında yasallaşmış ve günümüze kadar kullanımı her geçen gün yaygınlaşmıştır. Bireylere ihtiyaç duyduğu AP hizmetleri sunularak, doğurganlıkları ile ilgili bilinçli ve özgürce karar vermelerine olanak sağlanması amaçlanmıştır. Her ne kadar ülkemizde güvenilir AP yöntemleri ile ilgili hizmetler kullanıma sunulmuş olsa da, güvenilirliği düşük geleneksel yöntemlerin kullanımı hala oldukça yaygındır. ${ }^{1,2,8,9}$ İhtiyaç duyduğu gebeliği önleyici yönteme ulaşamayan ya da etkili olmayan gebeliği önleyici yöntem kullanan kadınların oranı oldukça yüksektir. ${ }^{7,8}$

Yapılan araştırmalar, riskli gebeliklerin AP yöntemlerinin etkili uygulanmasıyla büyük ölçüde önlenebileceğini göstermektedir. ${ }^{8,10,11}$ Bireylerin inanışlarının, yanlış bilgi ve uygulamalarının AP yöntemlerini kullanma durumunu etkileyen parametrelerin başında geldiği bilinmektedir. $\mathrm{Bu}$ nedenle sağlık profesyonellerinin etkili bir AP hizmeti sunabilmeleri için; bireylerin AP yöntemlerini kullanma durumları ve AP yöntemleri ile ilgili inanışları belirlenmeli ve AP yöntemlerinin kullanımına yönelik olumlu tutum geliştirmelerine olanak sağlayacak gereksinim duydukları nitelikli eğitim ve danışmanlık hizmetleri verilmelidir. ${ }^{11,12}$

Bu sistematik derleme; Türkiye'deki kadınların AP yöntemlerini kullanma durumlarını ve AP yöntemi kullanımına ilişkin tutumlarını belirlemek amacıyla yapılmıştır. Elde edilen verilerin ülkemizdeki kadınların AP yöntemleri hakkındaki uygulamalarının belirlenmesine ve sağlık profesyonellerinin AP danışmanlığını etkili bir şekilde planlamalarına ve sunmalarına katkı sağlayacağı düşünülmektedir.

\section{YÖNTEM}

Araştırma verileri, Türkiye'de 2007-2017 tarihleri arasında yapılmış, kadınların aile planlaması yöntemlerini ve bu konudaki bilgi ve uygulamalarını ortaya koymaya yönelik araştırmaların incelenmesiyle elde edilmiştir. "Aile planlaması yöntemleri”, "kadın", "Türkiye" ve "kadın sağlığı" anahtar kelimeleri Türkçe ve İngilizce olarak; Web of Science, PubMed, Science Direct, Medline, Ovid, Pro Quest, Google akademik ULAK BİM Türk Tıp Dizini veri tabanları, tez merkezi ve üniversite kütüphanelerinde taratılmıştır. Eylül 2007-Eylül 2017 tarihler arasında, örneklem seçim kriterlerine uyan ve tam metnine ulaşılabilen araştırmalar çalışmaya dahil edilmiştir. Elde edilen veriler iki araştırmacı tarafından birbirinden bağımsız olarak gözden geçirilmiş, özdeş çalışmalar çıkarılmıştır. Araştırmaya dahil edilme kriterlerine uyan 12 çalışma örneklemi oluşturmuştur (Şekil 1).

-Yurt içi ve yurt dışındaki bilimsel hakemli dergilerde yayınlanmış nicel araştırmalar,

-Türkiye'de yaşayan doğurgan çağdaki kadınları (15-49 yaş) kapsayan çalışmalar,

-Son on yıl içinde yayınlanan ulusal ve uluslararası bilimsel hakemli dergilerde yayınlanan araştırmalar, -Ulusal tez merkezinde tam metnine ulaşılabilen yüksek lisans ve doktora tezleri araştırmaya dahil edilmiştir.

\section{Araştırma dışında tutulma kriterleri;}

-Tam metnine ulaşılamayan,

-Yurt içi ve yurt dışında bilimsel hakemli dergilerde yayınlanmayan,

-Ulusal tez merkezinde tam metnine ulaşılamayan araştırmalar araştırma kapsamı dışında tutulmuştur. Araştırmada aşağıdaki soruların cevapları aranmıştır:

- Türkiye'de kadınların kullandıkları aile planlaması yöntemleri nelerdir?

- Türkiye'deki kadınların Aile Planlaması Yöntemleri kullanma durumu ile sosyodemografik özellikleri arasında bir ilişki var midir?

- Türkiye'deki kadınların aile planlaması yöntemlerini bilme durumları nedir?

- Türkiye'de kadınların kullandığı aile planlaması yöntemleri ile istenmeyen gebelikler arasında bir ilişki var mıdır?

Belirtilen veri tabanlarından elde edilen ve tam metnine ulaşılabilen araştırma makaleleri araştırma 
kapsamına alınmıştır. Elde edilen sonuçlar, araştırmanın yapıldığı yer, araştırma yöntemi, araştırma kapsamı ve sonuçları bakımından sistematik bir şekilde ele alınmış ve sonuçlar tartışma bölümünde irdelenmiştir.

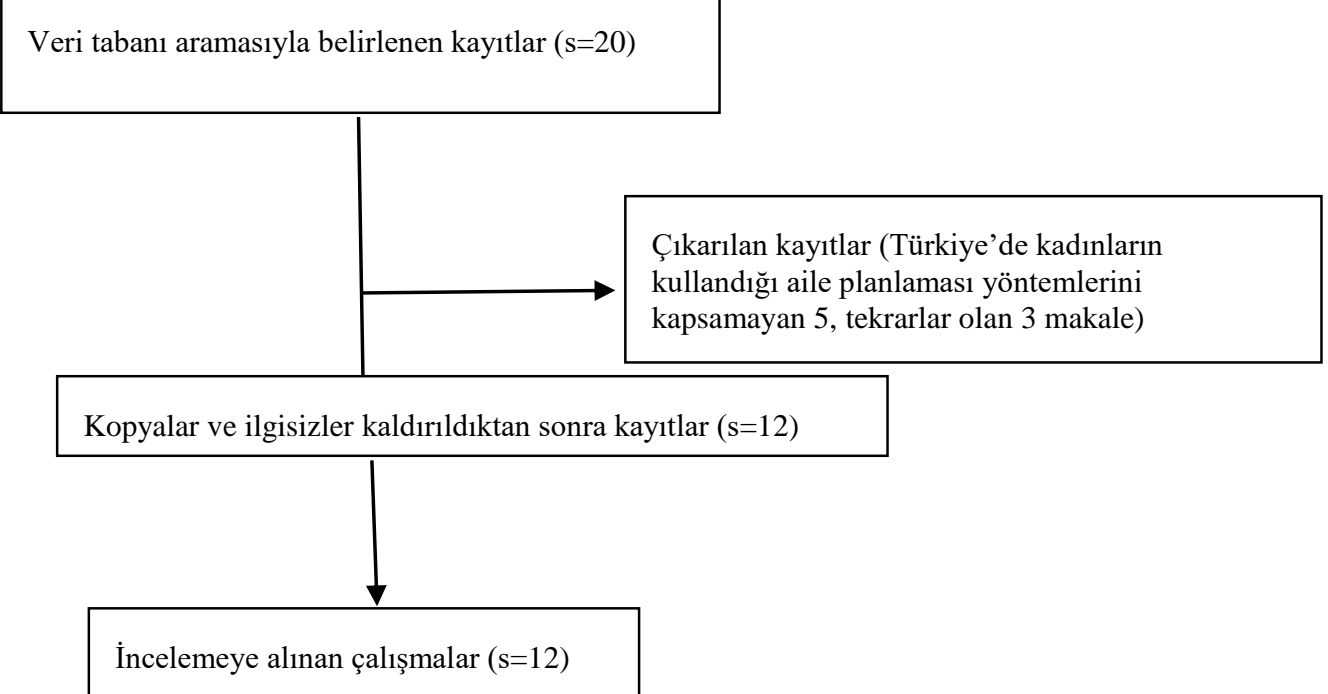

Şekil 1. Araştırma stratejisi ve akış şemasıı

\section{Araştırmanın Uygulanması}

Araştırmaya; yurt içi ve yurt dışında yayınlanan ve Türkiye'de kadınların kullandıkları aile planlaması yöntemlerini araştıran, 2007-2017 yıllarında yapılmış ve tam metnine ulaşılabilen araştırma makaleleri dahil edilmiştir. Araştırmaların değerlendirilmesinde, Polit ve Beck $^{13}$ tarafından önerilen 12 değerlendirme kriteri kullanılmıştır. Kriterler aşağıda belirtilmiştir.

1. Çalışmanın amacı ve araştırma soruları uygun şekilde belirtilmiş mi?

2. Araştırma soruları uygun şekilde cevaplanmış mı?

3. Araştırmada kullanılan terimler tanımlanmış mı?

4. Örneklemin özellikleri tanımlanmış mı?

5. Örnek büyüklüğü yeterli mi?

6. Kullanılan araç ve yöntemler uygun mu?

7. Araçlar güvenilir miydi?

8. Bulgular açık ve düzenli mi?

9. Önemli sonuçlar tartışılmış mı?

10. Bulgular tartışma ile uyumlu mu?

11. Sonuçlar özetlenmiş mi?

12. Sınırlamalar belirtilmiş mi?

Araştırmalar, iki araştırmacı tarafından birbirinden bağımsız olarak belirtilen kriterler açısından değerlendirilmiştir. Kriterlere uyan çalışmalara 1, uymayan çalışmalara ise 0 puan verilmiştir. Değerlendirme sonucunda, en yüksek skor 12, en düşük skor 7 olarak belirlenmiştir. Skorlar arası güvenirlik Kappa uyum analizi SPSS 11 kullanılarak belirlenmiş, Kappa uyum skoru 0.78 ve skorlar arası güvenirlik yüksek bulunmuştur $(\mathrm{p}=0.001)$

\section{BULGULAR}

Tablo 1'de değerlendirmeye alınan 12 çalışma yer almaktadır. Araştırmadan elde edilen bulgular; Araştırmanın tarihi, yazarı, yöntemi, çalışmanın yeri örneklem büyüklüğü, örneklemin özellikleri, veri toplama formunun özellikleri ve araştırma sonuçları olarak ele alındı (Tablo 2).

Türkiye'de kadınların kullandığı aile planlaması yöntemleri ile ilgili çalışmaların tamamının tanımlayıcı ve kesitsel çalışmalar olduğu, tekrarlayan ölçümler olmadığı, daha çok kişilere anket formlarının bir kez uygulanması ile verilerin elde edilmiş olduğu görüldü. Konu ile ilgili randomize kontrollü deneysel çalışmaya rastlanmadi.

Araştırmanın örneklemini genellikle doğurgan çağdaki kadınlar oluşturmaktaydı. Araştırmaların çoğunda örneklem büyüklüğü 400'ün altındaydı. En küçük örneklem büyüklüğünün $89,{ }^{2}$ En büyük örneklem büyüklüğünün ise 9.746 olduğu belirlendi. ${ }^{3}$

Araştırma verileri değerlendirildiğinde; genellikle farklı illerde yaşayan doğurgan çağdaki kadınlardan elde edilen veriler olduğu (Sivas, Malatya, Mersin, Konya, Şanlıurfa, Bingöl, Ankara, Gaziantep, Aydın 
vb.) ülke genelini kapsayan örneklemi içeren sadece bir çalışma olduğu görüldü. İl bazında yapılan çalışmaların çoğunlukla gelişmekte olan bölgelerin sonuçlarını yansıttığı belirlendi. Araştırma verilerinin 5 'i hastanelerin kadın doğum servislerinden, 6'sı Aile Sağlığı Merkezi (ASM) ve sağlık ocaklarından toplanmıştır.

\section{Tablo 1. Araştırmada değerlendirmeye alınan çalışmalar}

1.Aktoprak M. Evli kadınlar ve eşlerinin aile planlamasına yönelik tutumları ve ilişkili faktörler. [Yüksek Lisans Tezi]. Selçuk Üniversitesi Sağlık Bilimleri Enstitüsü Doğum ve Kadın Hastalıkları Hemşireliği Bilim Dalı, Konya, 2012.

2.Çayan A. 15-49 yaş evli kadınların aile planlaması yöntemlerine ilişkin tutumlarının kullandıkları kontraseptif yöntemler ile ilişkisi. [Yüksek Lisans Tezi]. Adnan Menderes Üniversitesi Sağlık Bilimleri Enstitüsü Doğum Kadın Sağlığı ve Hastalıkları Hemşireliği Anabilim Dalı, Aydın, 2009.

3.Doğaner G, Bilgiç D, Doğaner A, Umut ÜF, Kürk H, Çelik E. 15-49 yaş kadınların acil kontrasepsiyona ilişkin bilgi ve tutumları. Dokuz Eylül Üniversitesi Hemsirelik Yüksekokulu Elektronik Dergisi, 2011; 4(4):159-164

4.Ejder AS, Nazik E, Özdemir F, Pasinlioğlu T. Kadınların aile planlamasına ilişkin tutumlarının belirlenmesi. Anadolu Hemşirelik ve Sağllk Bilimleri Dergisi, 2010; 13: 3 .

5. Erenel AŞ, Kavlak T, Bingöl B. Kadınların doğum sonrası altı ay sonunda aile planlaması yöntemi kullanma durumu. Van Tip Dergisi, 2011; 18 (2):68-76.

6. Eryılmaz N, Ege E. Doğum sonu dönemdeki kadınların aile planlaması konusundaki tutumları ve ilișkili faktörler. Journal of Human Sciences, 2016; 13(2): 3389-3401.

7. Gözükara F, Kabalcıoğlu F, Ersin F. Sanlıurfa ilinde kadınların aile planlamasına ilișkin tutumlarının belirlenmesi. Harran Üniversitesi Tıp Fakültesi Dergisi [Journal Of Harran University Medical Faculty], Cilt 12, Sayı 1, 2015.

8. Karadağ G, Koçak HS, Yılmaz M. kadınların gebeliği önleyici yöntemleri kullanma ve tercih etme nedenleri. Gümüşhane Üniversitesi Sağlı Bilimleri Dergisi, 2013; 2(1).

9. Kaya M, Tatlı H, Açık Y, Deveci SH. Bingöl ili Uydukent sağlık ocağı bölgesindeki 15-49 yaş kadınların aile planlaması yöntemi kullanım düzeyinin belirlenmesi. Fırat Üniversitesi Sağlık Bilimleri Dergisi, 2008; 22 (4): 185-191.

10. Oltuluoğlu H, Başer M. Malatya il merkezinde yaşayan evli kadınların kullandıkları aile planlaması yöntemleri ve seçme nedenlerinin incelenmesi. İnönü Üniversitesi Tıp Fakültesi Dergisi, 2012; 19(3):167-74.

11. Sak ME, Evsen MS, Sak S, Çaça FN. Kontrasepsiyon yöntemlerinin etkinliği ve kadınların eğitim düzeyi: güneydoğu anadolu'da bir ilçe örneği. Dicle Tip Dergisi, 2008; 35(4):265-270.

12. Türkiye Nüfus ve Sağlık Araştırması 2013 temel bulgular. Hacettepe Üniversitesi Nüfus Etütleri Enstitüsü Sağlık Bakanlığı Ana Çocuk Sağlığı ve Aile Planlaması Genel Müdürlüğü, Ankara, 2013.

Kullanılan aile planlaması yöntemlerinin dağılımı incelendiğinde, araştırmaya göre oldukça değişen oranlarda farklı aile planlaması yöntemlerinin tercih edildiği belirlendi. Geleneksel bir yöntem olan geri çekme yönteminin araştırmaya göre değişmekle birlikte ilk siralarda tercih edilen yöntemlerden biri olduğu görüldü. Geri çekme yönteminin en düşük kullanım oranının \%9.1, en yüksek kullanım oranının ise \%61.3 olarak bulundu. Kondom kullanım oranı çalışmalarda en düşük \%13.2, en yüksek \%47.3 olarak belirtilmişti. Rahim içi araç (RİA) kullanım oranı ise en düşük \%19.1, en yüksek $\% 25.2$ olarak saptandı. Oral kontraseptif kullanım oranı ise en düşük \%13.9, en yüksek $\% 50.9$ olarak belirtilmişti. Çoğu çalışmada sosyal güvencesi olan, eğitim seviyesi yüksek olan ve çalışan kadınların APTÖ puanlarının yüksek olduğu belirlendi.

\section{TARTIȘMA}

$\mathrm{Bu}$ sistematik derlemede Türkiye'deki kadınların kullandıkları AP kullanma durumları ve AP yöntemi kullanmaya ilişkin tutumlarını belirlemeye yönelik olarak, seçim kriterlerine uyan ve tam metnine ulaşlabilen 12 adet araştırma makalesi incelenmiştir. Yapılan incelemelerde kadınların modern AP yöntemleri kullanma oranları istendik düzeyde değilken geleneksel yöntemleri kullanma oranları oldukça yüksektir. Derleme kapsamına alınan çalışmalarda örneklemin en fazla $29.874^{1}$ kişiden oluştuğu görülmüştür. Bunu takiben diğer çalışmalarda da $9,746^{3}, 1.600^{6}, 424^{12}$ gibi geniş örneklemler ile yapılan çalışma sayısının az olduğu saptanmıştır.

Aktoprak, ${ }^{11}$ kadınlar ve eşlerinin AP yöntemlerine ilişkin bilgi ve düşüncelerini incelediği çalışmasında; çiftlerin kullandıkları AP yöntemlerinin başında kondom yönteminin geldiğini belirlemiştir. Araştırmaya katılan kadınların ve eşlerinin bilgi kaynaklarının başında sağlık profesyonellerinin geldiği, büyük çoğunluğunun aldıkları danışmanlık hizmetinden memnun olduğu tespit edilmiştir. Çiftlerin çoğunluğunun AP yöntemleri ile ilgili bilgi düzeylerinin iyi olduğu ve AP yöntemi kullanma kararını eşlerin birlikte alması gereken bir karar olduğunu düşündükleri belirlenmiștir.

Çayan ${ }^{1}$ çalışmasında, kadınların çoğunun bir AP yöntemi kullandı̆̆ını, modern yöntemlerden en çok kondom, hap ve RİA tercih ettiklerini, kullandıkları geleneksel yöntemlerin başında geri çekme yönteminin geldiğini tespit etmiştir. AP yöntemi kullanan kadınların çoğunun modern yöntem, küçük 
bir kısmının da geleneksel yöntem kullandığ1 görülmüştür.

Tablo 2. Değerlendirmeye alınan araştırmaların irdelenmesi

\begin{tabular}{|c|c|c|c|c|c|}
\hline Yer & Örneklem & $\begin{array}{l}\text { Araştırma } \\
\text { yöntemi }\end{array}$ & $\begin{array}{l}\text { Veri } \\
\text { toplama } \\
\text { aracı }\end{array}$ & AP kullanım sıklığı (\%), APTÖ ve etkileyen faktörler & $\begin{array}{l}\text { Kalite } \\
\text { skoru }\end{array}$ \\
\hline $\begin{array}{l}\text { Mersin } \\
\text { Silifke ASM }\end{array}$ & $\begin{array}{l}166 \text { evli kadın } \\
\text { ve eşleri }\end{array}$ & Tanımlayıcı & $\begin{array}{l}\text { Anket } \\
\text { APTÖ }\end{array}$ & $\begin{array}{l}\text { Kadınlar ve eşlerin \% 89,8'inin AP yöntemi kullandığı } \\
\text { Kondom:47.3, RİA:25.2, Geri çekme: } 9.1 \\
\text { İşsizlik, kürtaj olma, çocuk sahibi olmak isteme, AP yöntemi } \\
\text { kullanmama, ileri yaş gebeliği sağlıklı bulma ve AP } \\
\text { danışmanlığı almama kadınlarda AP kullanım durumunu } \\
\text { olumsuz yönde etkileyen risk faktörleridir. }\end{array}$ & 11 \\
\hline $\begin{array}{l}\text { Aydın } \\
\text { Sağlık Ocağı }\end{array}$ & $\begin{array}{l}15-49 \text { yaş } \\
\text { grubundaki } \\
427 \text { evli kadın }\end{array}$ & $\begin{array}{l}\text { Kesitsel } \\
\text { tanımlayıcı }\end{array}$ & $\begin{array}{l}\text { Anket } \\
\text { APTÖ }\end{array}$ & $\begin{array}{l}\text { Geri çekme: } 61.1 \text {, Kondom:46.1, Hap: } 40.8 \text {, RİA: } 36.7 \\
\text { Araşırmada çocuk sahibi olmak istediği için AP yöntemi } \\
\text { kullanmayan, en fazla modern yöntemlere güvenen kadınların } \\
\text { APTÖ toplam puan ortalamalarının daha yüksek olduğu ve aile } \\
\text { planlaması yöntemlerine karşı tutumlarının istenilen düzeyde } \\
\text { olduğu görülmüştür. }\end{array}$ & 10 \\
\hline $\begin{array}{l}\text { Sivas } \\
\text { Sağlık ocağı }\end{array}$ & $\begin{array}{l}15-49297 \\
\text { Kadın }\end{array}$ & Tanımlayıcı & Anket & $\begin{array}{l}\text { Kadınların \%65.2'si acil kontrasepsiyon ve yöntemleri } \\
\text { konusunda bilgi sahibi değillerdir. } \\
\text { Kadınların \%27'si son cinsel ilişkisinde AP yöntemi } \\
\text { kullanmamıştır. }\end{array}$ & 8 \\
\hline $\begin{array}{l}\text { Belirtilmemiş } \\
\text { Hastane }\end{array}$ & 424 kadın & Tanımlayıcı & $\begin{array}{l}\text { Anket } \\
\text { APTÖ }\end{array}$ & $\begin{array}{l}\text { AP yöntemi kullanma \% } 57.5 \\
\text { Modern yöntem kullanma \% } 91.8 \\
\text { Eğitim düzeyi yüksek olan, yaşı genç olan kadınlarda APTÖ } \\
\text { yüksek bulunmuş. Aile planlamasına karşı tutumlarının } \\
\text { istendik düzeyde olmadığı belirlenmiştir. }\end{array}$ & 8 \\
\hline $\begin{array}{l}\text { Ankara } \\
\text { Hastane }\end{array}$ & $\begin{array}{l}\text { Doğum sonu } \\
\text { ilk altı ayı } \\
\text { tamamlayan } \\
230 \text { kadın }\end{array}$ & Tanımlayıcı & Anket & $\begin{array}{l}\text { Kadınların \%72.6’sı gebe kalmadan önce herhangi bir yöntem } \\
\text { kullanmış. Kadınların \% } 94.3 \text { doğum sonrası ilk altı ay sonunda } \\
\text { yöntem kullanmış. Yöntemler Doğum öncesi, doğum sonrası } \\
\text { sırasıyla kondom (\% } 31.7 \text { - \%42.0) 1. Sırada Geri çekme } \\
\% 16.1 \text { - \%26.7). }\end{array}$ & 8 \\
\hline
\end{tabular}

$\begin{array}{llll}\text { Konya } & 272 \text { Kadın } & \text { Tanımlayıcı } & \text { Anket } \\ \text { Hastane } & & \text { APTÖ }\end{array}$

Çalışan, lise ve üzeri eğitim görmüş, çekirdek aile ferdi olan, ekonomik durumunu iyi olarak algilayan kadınlarda, sosyal güvencesi olan, AP danışmanlık hizmeti alan ve doğum sonu AP kullanmayı düşünen kadınlarda APTÖ puanının yüksek olduğu belirlenmiştir.

\begin{tabular}{|c|c|c|c|c|c|}
\hline $\begin{array}{l}\text { Şanliurfa } \\
\text { Hastane }\end{array}$ & 89 Evli Kadın & Tanımlayıcı & APTÖ & $\begin{array}{l}\text { 17-34 yaş grubundaki kadınların, sosyal güvencesi olanların, } \\
\text { yüksek eğitim düzeyine sahip olan APTÖ puanlarının daha } \\
\text { yüksek olduğu belirlenmiştir. }\end{array}$ & 8 \\
\hline $\begin{array}{l}\text { Gaziantep } \\
\text { Sağlik Ocağı }\end{array}$ & 165 Kadın & Tanımlayıcı & Anket & $\begin{array}{l}\text { \%70.9'unun daha önce herhangi bir AP yöntemi kullandığı, } \\
\text { bunlardan \%50.9' unun oral kontraseptif, \%37.6'sının } \\
\text { kondomla, \% 6.7'sinin RİA ile korunduğu belirlenmiştir. }\end{array}$ & 8 \\
\hline $\begin{array}{l}\text { Bingöl } \\
\text { Sağlik Ocağı }\end{array}$ & $\begin{array}{l}15-49 \text { yaş } \\
\text { arası } 303 \\
\text { Kadın }\end{array}$ & Tanımlayıcı & Anket & $\begin{array}{l}\text { Geri çekme: \%23.1'i RİA,\%21.5'i kondom:\%19.8'i, hap: } \\
\% 13.9\end{array}$ & 8 \\
\hline $\begin{array}{l}\text { Malatya } \\
\text { Sağlık } \\
\text { Ocağı }\end{array}$ & $\begin{array}{l}15-49 \text { yaş } \\
\text { arası } 1600 \\
\text { evli kadın }\end{array}$ & Tanımlayıcı & Anket & $\begin{array}{l}\text { \%62,3'ü modern, \%37,7'si geleneksel AP yöntemi } \\
\text { Geri çekme: \%35.5, RÍA: \%25.1 Kondom: \%20.3 } \\
\text { Modern AP yöntemi kullanımı; genç, eğitimli } \\
\text { çiftler, memur, gebeliği, doğumu ve çocuk sayısı az olan } \\
\text { kadınlarda fazladır. }\end{array}$ & 9 \\
\hline $\begin{array}{l}\text { Ergani } \\
\text { Hastane }\end{array}$ & $\begin{array}{l}\text { Kontraseptif } \\
\text { yöntem } \\
\text { kullanan } 152 \\
\text { Multipar } \\
\text { Kadın }\end{array}$ & Tanımlayıcı & Anket & $\begin{array}{l}\text { Geri çekme:\% 42.1, RİA:\%19.1, oral kontraseptif: \%15.8, } \\
\text { Kondom: \%13.2, Tüp Ligasyonu: \% } 7.2 \\
\text { Eğitim seviyesi arttıça, RİA ve oral kontraseptif kullanımı } \\
\text { artmış. } \\
\text { İstenmeyen gebelikler geri çekme yönteminde en fazla, RİA'da } \\
\text { en az. }\end{array}$ & 8 \\
\hline $\begin{array}{l}\text { Türkiye } \\
\text { Nüfus ve } \\
\text { Sağlık } \\
\text { Araştırması- } \\
2013 \text { TNSA. }\end{array}$ & $\begin{array}{l}\text { Doğurgan } \\
\text { çağdaki 9,746 } \\
\text { Kadın }\end{array}$ & $\begin{array}{l}\text { Kesitsel } \\
\text { Tanımlayıcı }\end{array}$ & Anket & $\begin{array}{l}\text { Geri çekme } 15-19 \text { yaş grubunda en yüksek, \%28. RİA 35-39 } \\
\text { yaş grubundaki evli kadınlar arasında }(\% 21) \text { diğer yaş } \\
\text { grubundaki kadınlara göre daha yaygın }\end{array}$ & 12 \\
\hline
\end{tabular}


Kullanılan modern yöntemlerin sırasıyla; RİA, hap ve kondom olduğu, geleneksel yöntem kullanımının oldukça fazla olduğu ve ilk sırada geri çekme yönteminin kullanıldığı belirlenmiştir. Kadınların yaklaşık üçte birinin yöntem kullanırken gebe kaldığ1, yöntem kullanırken gebe kalma oranının geri çekme yönteminde en yüksek olduğu (\%72.5) saptanmıştır. Modern yöntemlerin kadınların en çok güvendiği AP yöntemleri olduğu görülmüştür.

Doğaner ve ark. ${ }^{4}$ çalışmasında acil kontraseptif yöntemlerini bilen ve kullanan kadınlarda istenmeyen gebeliklerin daha az olduğu saptanmıştır.

Ejder Apay ve ark. ${ }^{12}$ çalışmasında kadınların gebelik sayısı, yaşayan çocuk, doğum ve abortus sayısı attıkça APTÖ tutum puanlarının daha düşük olduğu belirlenmiştir. AP yöntemi kullananların; kullanmayanlara ve modern yöntem kullananların geleneksel yöntem kullananlara göre APTÖ puanlarının yüksek olduğu, AP yöntemi kullanma süresi arttıkça APTÖ puanlarının arttığı, AP yöntemi kullanmaya kendisi karar verenlerin APTÖ puanlarının daha yüksek olduğu belirlenmiştir.

Erenel ve ark..$^{5}$ çalışmasında; kadınların doğumdan sonraki ilk altı ayda AP yöntemi kullanma durumlarının yaş, doğum şekli, eğitim durumu, AP konusunda bilgi sahibi olma durumundan etkilenmediği, doğum öncesi dönemde yöntem kullanma durumundan etkilendiği belirlenmiştir.

Eryılmaz ve Ege $\mathrm{E}^{7}$ çalışmasında, kadınların çoğunun AP danışmanlık hizmeti aldığı, büyük bir çoğunluğunun AP yöntemlerine ilişkin bilgilerini sağlık profesyonellerinden öğrendiği, doğumdan sonra kullanmak istedikleri AP yönteminin "RİA" olduğu tespit edilmiştir.

Gözükara ve ark. $^{2}$ çalışmalarında, kadınların aile planlamasına karşı tutumları olsa da, istendik düzeyde olmadığını belirlemişlerdir. Ayrıca eğitim düzeyi yüksek olan, genç yaşta olan, gebelik sayısı az olan, sosyal güvencesi olan, çekirdek aile yapısına sahip olan, AP yöntemine eşi ile birlikte karar veren kadınların APTÖ puanlarının daha yüksek olduğu saptanmıştır. Aile planlaması yöntemi ve modern yöntem kullanmayanlarda APTÖ puan ortalamalarının daha düşük olduğu görülmüştür.

Karadağ ve ark. ${ }^{9}$ çalışmasında, kadınların tamamının gebeliği önleyici yöntem kullandığı belirlenmiştir. Kaya ve ark. ${ }^{10}$ çalışmasında, kadınların büyük çoğunluğunun bir AP yöntemi kullandığg, bu yöntemlerin yarısından fazlasının etkin yöntemler, yaklaşık dörtte birinin ise etkisiz yöntemler olduğu saptanmıştır. En sık kullanılan yöntemlerin sırasıyla; geri çekme, RİA, kondom ve hap olduğu belirlenmiştir. Oltuluoğlu ve ark. ${ }^{6}$ çalışmasında, kadınların yarısından fazlasının modern AP yöntemleri, \%30'undan fazlasının ise geleneksel AP yöntemleri kullandıkları saptanmıştır. En çok kullanılan yöntemler arasında geri çekmenin birinci sırada yer aldığı, onu RİA ve kondomun takip ettiği görülmüştür. Modern AP yöntemlerini; genç yaştaki eğitimli çiftlerin, gebelik ve çocuk sayısı az olan kadınların kullandıkları tespit edilmiştir.

Sak ve ark. ${ }^{8}$ çalışmasında; en sık kullanılan yöntemin geri çekme olduğu, bunu sırasıyla; RİA, oral kontraseptifler, kondom, tüp ligasyonu ve diğer AP yöntemlerinin izlediği belirlenmiştir.

TNSA 2013 verilerinde ise geri çekme yöntemi, 15-19 yaş grubunda en yüksek düzeye ulaşmaktadır (\%28). En çok tercih edilen modern yöntemlerden olan RİA’nın, 35-39 yaş grubundaki evli kadınlar arasında kullanımı (\%21) diğer yaş grubundaki kadınlara göre daha yaygındir. ${ }^{3}$

\section{SONUÇ}

Çalışmalarda görüldüğü üzere, AP yöntemleri kullanım oranları farklılık göstermekle birlikte, araştırmalardan elde edilen ortak sonuç, modern AP yöntemleri kullanımının istendik düzeyde olmadığı, buna karşın geri çekme yöntemi kullanımının oldukça yaygın olduğu, eğitim düzeyi yüksek olan, sosyal güvencesi olan ve çalışan kadınların AP yöntemlerine ilişkin tutumlarının daha olumlu olduğu şeklindedir.

Modern AP yöntemlerinin kullanımını arttırmak için, AP eğitimlerinin etkinliğinin arttırılması, danışmanlık hizmetlerinin planlanması ve etkin şekilde uygulanması gerekmektedir. Araştırmadan elde edilen sonuçların AP hizmetlerinin etkinliğinin arttırılmasında, AP eğitimlerinin kapsam ve içeriğinin belirlenmesinde yol gösterici olacağı düşünülmektedir.

\section{KAYNAKLAR}

1. Çayan A. 15-49 Yaş Evli Kadınların aile planlaması yöntemlerine ilişkin tutumlarının kullandıkları kontraseptif yöntemler ile ilişkisi. Adnan Menderes Üniversitesi Sağlık Bilimleri Enstitüsü Doğum Kadın Sağlığı ve Hastalıkları Hemşireliği Anabilim Dalı Yüksek Lisans Tezi, Aydın, 2009.

2. Gözükara F, Kabalcıoğlu F, Ersin F. Şanlıurfa ilinde kadınların aile planlamasına ilişkin tutumlarının belirlenmesi. Harran Üniversitesi Tip Fakültesi Dergisi. 2015;12(1):9-16.

3. Türkiye Nüfus ve Sağlık Araştırması 2013 Temel Bulgular. Hacettepe Üniversitesi Nüfus Etütleri Enstitüsü Să̆lık Bakanlığı Ana Çocuk Sağlığı ve Aile Planlaması Genel Müdürlüğü, Ankara, 2013.

4. Doğaner G, Bilgiç D, Doğaner A, Umut ÜF, Kürk H, Çelik E. 15-49 yaş kadınların acil kontrasepsiyona ilişkin bilgi ve tutumları. Dokuz Eylül Üniversitesi Hemşirelik Yüksekokulu Elektronik Dergisi. 2011;4(4):159-164.

5. Erenel AŞ, Kavlak T, Bingöl B. Kadınların doğum sonrası altı ay sonunda aile planlaması yöntemi kullanma durumu. Van Tip Dergisi. 2011;18(2):68-76. 
6. Oltuluoğlu H, Başer M. Malatya il merkezinde yaşayan evli kadınların kullandıkları aile planlaması yöntemleri ve seçme nedenlerinin incelenmesi. İönü Üniversitesi Tıp Fakültesi Dergisi. 2012;19(3):167-174.

7. Eryılmaz N, Ege E. Doğum sonu dönemdeki kadınların aile planlaması konusundaki tutumları ve ilişkili faktörler. Journal of Human Sciences. 2016;13(2):33893401.

8. Sak ME, Evsen MS, Sak S, Çaça FN. Kontrasepsiyon yöntemlerinin etkinliği ve kadınların eğitim düzeyi: güneydoğu Anadolu'da bir ilçe örneği. Dicle Tip Dergisi. 2008;35(4):265-270.

9. Karadağ G, Koçak HS, Yılmaz M. Kadınların gebeliği önleyici yöntemleri kullanma ve tercih etme nedenleri. Gümüşhane Üniversitesi Sağlık Bilimleri Dergisi. 2013;2(1):13-25.

10. Kaya M, Tatlı H, Açık Y, Deveci SH. Bingöl İli Uydukent Sağlı Ocağı bölgesindeki 15-49 yaş kadınların aile planlaması yöntemi kullanım düzeyinin belirlenmesi. Firat Üniversitesi Sağllk Bilimleri Dergisi. 2008;22(4):185-191.

11. Aktoprak M. Evli Kadınlar ve eşlerinin aile planlamasına yönelik tutumları ve ilişkili faktörler. Selçuk Üniversitesi Sağlık Bilimleri Enstitüsü Doğum ve Kadın Hastalıkları Hemşireliği Bilim Dalı Yüksek Lisans Tezi, Konya, 2012.

12. Ejder AS, Nazik E, Özdemir F, Pasinlioğlu T. Kadınların aile planlamasına ilişkin tutumlarının belirlenmesi. Anadolu Hemşirelik ve Sağllk Bilimleri Dergisi. 2010;13(3):1-6.

13. Polit DF, Beck CT. Literature reviews: Finding and reviewing research evidence. In DF. Polit, BC. Tatano (Eds.), Essentails of nursing research: ppraising evidencefor nursing practice 7th ed. Philadelphia: Lippincott Williams \& Wilkins; 2009:169-193. 